\section{Australian Journal of \\ Crop Science}

AJCS 13(04):558-565 (2019)

doi: 10.21475/ajcs.19.13.04.p1496

\title{
Implication of some pre-germination treatments on seeds and initial seedling growth of pomegranate (Punica granatum L.)
}

\author{
Laís Naiara Honorato Monteiro ${ }^{1 *}$, Aparecida Conceição Boliani ${ }^{2}$, Antonio Flávio Arruda Ferreira ${ }^{2}$, Maria \\ Gabriela Fontanetti Rodrigues ${ }^{2}$, Gláucia Amorim Faria ${ }^{3}$, Marcela Sant'anna Cordeiro da Silva ${ }^{4}$, Marcela \\ Pacola Oliveira ${ }^{5}$, Silvia Regina Cunha ${ }^{1}$, Luiza Rocha Ribeiro ${ }^{1}$
}

${ }^{1}$ Department of Horticulture, Universidade Estadual Paulista (UNESP), School of Agriculture, José Barbosa de Barros Street, Postcode 18610-307, Botucatu, SP, Brazil

${ }^{2}$ Department of Plant technology, Food technology and Socioeconomics, Universidade Estadual Paulista (UNESP), Engineering College, Monção Street, Postcode 15385-000, Ilha Solteira, SP, Brasil

${ }^{3}$ Department of Matemathics, Universidade Estadual Paulista (UNESP), Engineering College, Rio de Janeiro Street, Postcode 15385-000, Ilha Solteira, SP, Brasil

"Department of Vegetable Production, University of São Paulo (USP), Agriculture college "Luiz de Quiroz", Pádua Dias Avenue, Postcode 13418-900, Piracicaba, SP, Brasil

${ }^{5}$ Department of Soils, Federal University of Mato Grosso do Sul, MS 306 Road, 105Km, Postcode 79560-000, Chapadão do Sul, MS, Brasil

\section{*Corresponding author: laismonteiiro@gmail.com}

\begin{abstract}
Pomegranate stands out as healthy fruit due to its phytochemical compounds. Some dormancy studies have stated the need to understand seed physiology, subsequent seedling production, as producers intended to expand the supply of pomegranate, besides facilitating the introduction of such promising crop. Thus, this study aimed to identify possible integumentary dormancy in seeds of pomegranate cultivar Comum and to evaluate the effect of mechanical scarification and water immersion of seeds, as overcoming method. In this study, sarcotesta was removed from scarified and non-scarified seeds, and then immersed in deionised water for up to $0,12,24$ and 48 hours. Then seeds were embedded in trays of expanded polystyrene with organic substrate at greenhouse. The following evaluations were carried out: initial emergence, speed index, mean time of emergence and emergence percentage, besides biometric variables such as leaf number, stem diameter, length of aerial part and root system, fresh matter and total dry matter. A $2 \times 4$ factorial arrangement (presence or absence of scarification $\times$ four immersion time) in a completely randomized design was used, with 4 replicates of 25 seeds each. The results showed that seeds do not need to be scarified and immersed in water, regarding to both emergence and initial seedling growth variables. Results indicated that it was unnecessary to perform scarification and water immersion for emergence and initial growth variables, leading to conclusion that pomegranate seeds cv. Comum have no integumentary dormancy.
\end{abstract}

Keywords: Dormancy; pomegranate; rootstock; sarcotesta; scarification.

Introduction

Recently, there has been a worldwide trend to research on nutraceutical values of foods to be included in the diet. Bioactive compounds found in pomegranate (Punica granatum L.) have been studied in recent decades, since they can be used by nutraceutical manufacturers. Polyphenols (tannins), flavonoids, alkaloids, organic acids, as well as saccharides, coumarins and lignans are among the compounds are found in pomegranate (Elfalleh et al., 2011; El-Sherbini and Shoukry, 2012; Russo et al., 2018).

Pomegranate studies have been growing, along with its market demand. Therefore, the production system must be optimized. Finding a suitable cultivar helps to have better agronomic traits to produce rootstocks, besides providing fruit quality to orchard management procedures and high quality fruit yield (Franzon et al., 2010).

According to Mendonça and Mendonça (2013) and Shalimu et al. (2015), the use of seeds in agriculture is not only related to the natural process of spreading and perpetuating species, breeding and developing new cultivars, but also recommended for rootstocks production in fruit culture. The seedlings produced by this material present a more vigorous and deep root system, an important feature to aid in the absorption of nutrients and resistance to water deficit. Furthermore, plant seeds can be adapted to certain soil and climate conditions to provide greater orchard longevity 
(Vazifeshenas et al, 2009; Fischer et al., 2013; Peche et al., 2016).

Similarly to pomegranates, papaya and passion fruits (Melo and Seleguini, 2013, Aguiar et al., 2014) also present a fleshy seed coat called sarcotesta, which possibly enables dormancy, as it is resistant and impermeable (Noda et al., 2002; Shalimu et al., 2015; Silva et al., 2015).

Moreover, this possible dormancy may be associated to sarcotesta development due to presence of phenolic compounds, anthocyanins and tannins, since they lead to antagonistic factor on seedling germination and emergence. However, Ibrahim et al. (2011) stated that the levels or concentrations of these possible inhibitors vary according to genotypes, some of which may not have them. In natural conditions, the germination of pomegranate seeds encounter difficulties (Materechera and Seeiso, 2013). Therefore, the use of pre-sowing treatments on seeds germination is essential, as they avoid unfavourable germination condition and uneven emergence, which compromise commercial rootstock production (Zaidan and Barbedo, 2004; Oliveira, 2007, Leite et al., 2012).

Among pre-sowing treatments on seeds germination to overcome dormancy, one should prioritise those that are simple and offer reduction of the time between sowing and emergence, because embeding of seeds in the substrate for long period, without the occurrence of germination, exposes the material to harmful factors (Scalon and Jeromine, 2013), such as excess moisture, pathogens and pests.

In this way, mechanical scarification and water immersion of seeds are methods that can be used for germination efficiency. Furthermore, mechanical scarification through tegument disruption enables gas exchange and water absorption, consequently, increase in germination speed, percentage and emergence (Fachinello et al., 2005, Ferreira and Gentil, 2006, Nazário and Ferreira, 2010).

Thus, this study aimed (1) to evaluate the effect of mechanical scarification and water immersion of pomegranate seeds without sarcotesta to overcome integument dormancy and (2) to reduce germination and emergence period and (3) to find the best initial seedling growth for rootstock production.

\section{Results and discussion}

\section{Emergence of pomegranate seedlings}

Table 1. shows the mean values of the analyzed variables, but there was only a significant interaction in tested factors for initial emergence and mean time of emergence.

The emergence percentages of scarified seeds were lower than non-scarified ones in all water immersion periods. During the course of experiment, pomegranate seeds were viable since absorption of certain amount of water triggered a series of events that was initiated by imbibition and closed embryo emergence (Bewley et al., 2013).

For scarified seeds, the highest emergence value was found when they were immersed in water for 12 hours (42\%) but did not differ significantly from other periods. These results were similar to those found in scarified seeds of passion fruit
(49.5\%) immersed in water for the same length of time (Wagner Júnior et al., 2005).

Emergence value may have dropped in scarified seeds over immersion periods, since seeds present higher water volume during wider imbibition periods, besides that the excess of moisture can prevent oxygen from entering the embryo, which reduces all metabolic process; consequently, affecting germination and vigour potentials (Brasil, 2009; Ferreira et al., 2014).

However, emergence value was higher than $50 \%$ in all treatments. The highest value $(65 \%)$ was observed when seeds were not immersed in water ( 0 hours). However, different results were found in non-scarified seeds of passion fruit, as the highest emergence value was immersed in water for 24 hours, according to Wagner Júnior et al. (2005).

Emergence values of non-scarified seeds were higher than scarified ones in all treatments, where they did not present a physical impediment in seed water intake, disregarding the possibility of dormancy due to the hardness of integument. Our results appear to corroborate with Takata et al. (2014) on imbibition curve of the seed species, concluding that seeds initially present low water content, but rapidly increase during the first two hours; then slowly increased until reaching stability (germination phase I). This short-term characteristic is an advantage in pomegranate seeds. Thus, if pre-germination treatments are required, they will be quickly performed.

In all treatments, there were variations in the rates of emergence speed index (ESI) but did not differ significantly between them. For scarified seeds, the highest result was observed when seeds were immersed in water for 12 hours (0.7563). For non-scarified seeds, the highest value was found in water immersion for 24 hours (0.7324). Probably, seeds did not suspend metabolic and water absorption activities during the aforementioned periods, which culminated in higher ESI values.

Our results also corroborates with Wagner Júnior et al. (2005) on scarified seeds of passion fruit immersed in water for 12 hours (1.29) and non-scarified in water immersion for 24 hours (1.19). Comparison of their results with the results of this study showed that the first group of seeds was superior to the second, which also occurred in our study.

Lower ESI values imply lower emergence percentages. According to Dutra et al. (2012), higher ESI results are preferable, as seeds will have low probability of deteriorating under environmental conditions, as well as reducing nursery period.

Initial emergence (IE) of scarified seeds was lower in water immersion for 12 hours (5.50 days); therefore, there were statistically significant differences from other periods. For non-scarified seeds, the lowest value was 12.50 days, when seeds were not immersed; however, there was no significant difference between periods (Table 2).

In an experiment with scarification and water immersion of passion fruit seeds (Passiflora edulis), Wagner Júnior et al. (2005) observed a 21-day initial emergence; thus, longer than that found in the current study for both scarified and non-scarified seeds. 
Table 1. Analysis of variance for IE (initial emergence), E (emergence percentage), ESI (emergence speed index) and MTE (mean time of emergence) in pomegranate seeds (Punica granatum L.) immersed in water.

\begin{tabular}{|c|c|c|c|c|}
\hline \multirow{2}{*}{ Treatments } & IE (days) & $E(\%)$ & ESI & MTE $\left(\right.$ days $\left.^{-1}\right)$ \\
\hline & \multicolumn{4}{|c|}{ p Value } \\
\hline Seeds (S) & $<0.01^{*}$ & $<0.01^{*}$ & $0.4883^{\mathrm{ns}}$ & $<0.01^{*}$ \\
\hline Immersion (I) & $0.0987^{\mathrm{ns}}$ & $0.8268^{\mathrm{ns}}$ & $0.8531^{\mathrm{ns}}$ & $0.1238^{\mathrm{ns}}$ \\
\hline SxI & $0.0243^{*}$ & $0.8353^{\mathrm{ns}}$ & $0.3107^{\mathrm{ns}}$ & $0.0217^{*}$ \\
\hline C.V. (\%) & 17.99 & 26.32 & 30.93 & 12.75 \\
\hline Overall mean & 11.22 & 49.25 & 0.65 & 21.59 \\
\hline Non-scarified & 13.81 & 58.75 & 0.68 & 23.82 \\
\hline Scarified & 8.63 & 39.75 & 0.63 & 19.36 \\
\hline Immersion (hours) & \multicolumn{4}{|c|}{ Overall mean } \\
\hline 0 & 11.50 & 46.50 & 0.62 & 20.55 \\
\hline 12 & 9.88 & 48.50 & 0.68 & 20.82 \\
\hline
\end{tabular}

"Significant; ${ }^{\mathrm{NS}}$ Not significant at $5 \%$ probability by F test; C.V. = Coefficient of variation.
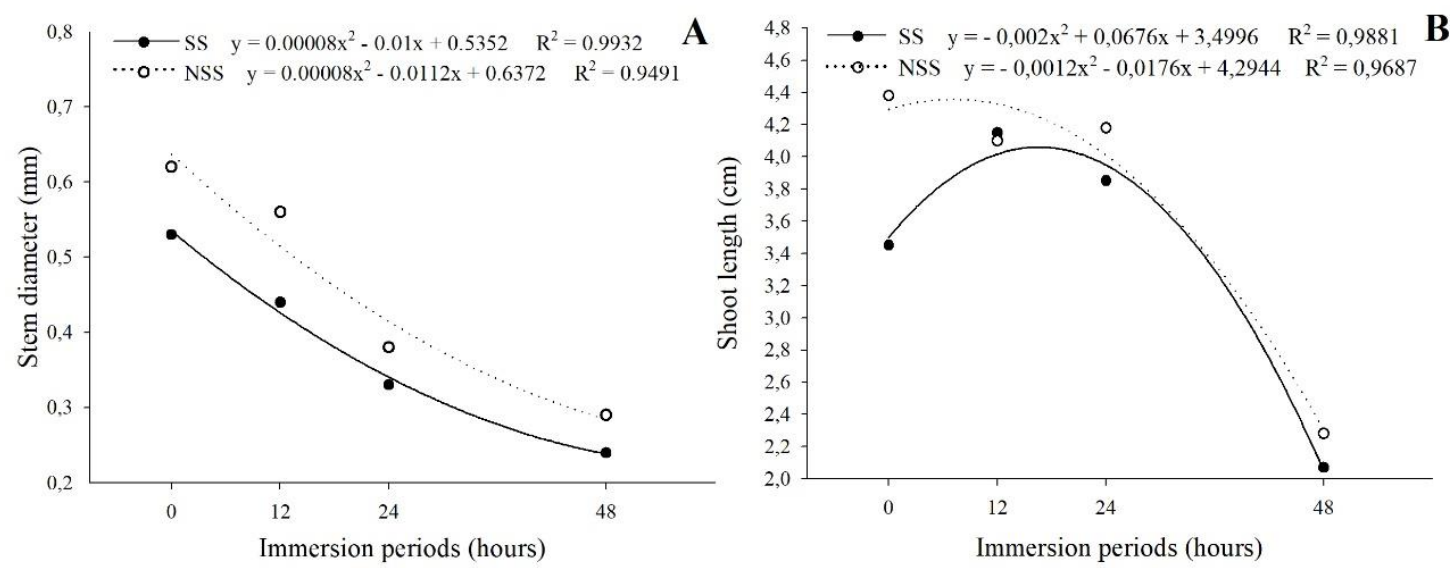

Fig 1. Stem diameter (A) and shoot length (P) of pomegranate seedlings (Punica granatum L.) according to presence (SS) or absence (NSS) of scarification in seeds during water immersion periods.

Table 2. Values of IE (initial emergence) and MTE (mean time of emergence) of pomegranate (Punica granatum L.) seedlings according to seed scarification and immersion periods.

\begin{tabular}{lcc}
\hline \multirow{2}{*}{ Immersion periods (h) } & SS & NSS \\
\cline { 2 - 3 } & \multicolumn{2}{c}{ IE (days) } \\
\hline 0 & $10.50 \mathrm{Aa}$ & $12.50 \mathrm{Aa}$ \\
12 & $5.50 \mathrm{Bb}$ & $14.25 \mathrm{Aa}$ \\
24 & $10.00 \mathrm{Ab}$ & $15.00 \mathrm{Aa}$ \\
48 & $8.50 \mathrm{Ab}$ & $13.50 \mathrm{Aa}$ \\
\hline MEAN & 8.63 & 13.81 \\
\hline C.V. (\%) & \multicolumn{2}{c}{17.99} \\
\hline PERIODS (h) & \multicolumn{2}{c}{$\mathrm{MTE}\left(\right.$ days $\left.^{-1}\right)$} \\
\hline 0 & $18.56 \mathrm{Ba}$ & $22.54 \mathrm{Aa}$ \\
12 & $15.96 \mathrm{Bb}$ & $25.68 \mathrm{Aa}$ \\
24 & $19.54 \mathrm{Ba}$ & $23.93 \mathrm{Aa}$ \\
48 & $23.38 \mathrm{Aa}$ & $23.12 \mathrm{Aa}$ \\
\hline MEAN & 19.36 \\
\hline CV (\%) & \multicolumn{2}{c}{12.75} \\
\hline Equivalent letters in column and lowercase in row do not differ from each another by Scott-knott test at 5\% probability. SS \\
$=$ scarified seeds, NSS = non-scarified seeds.
\end{tabular}



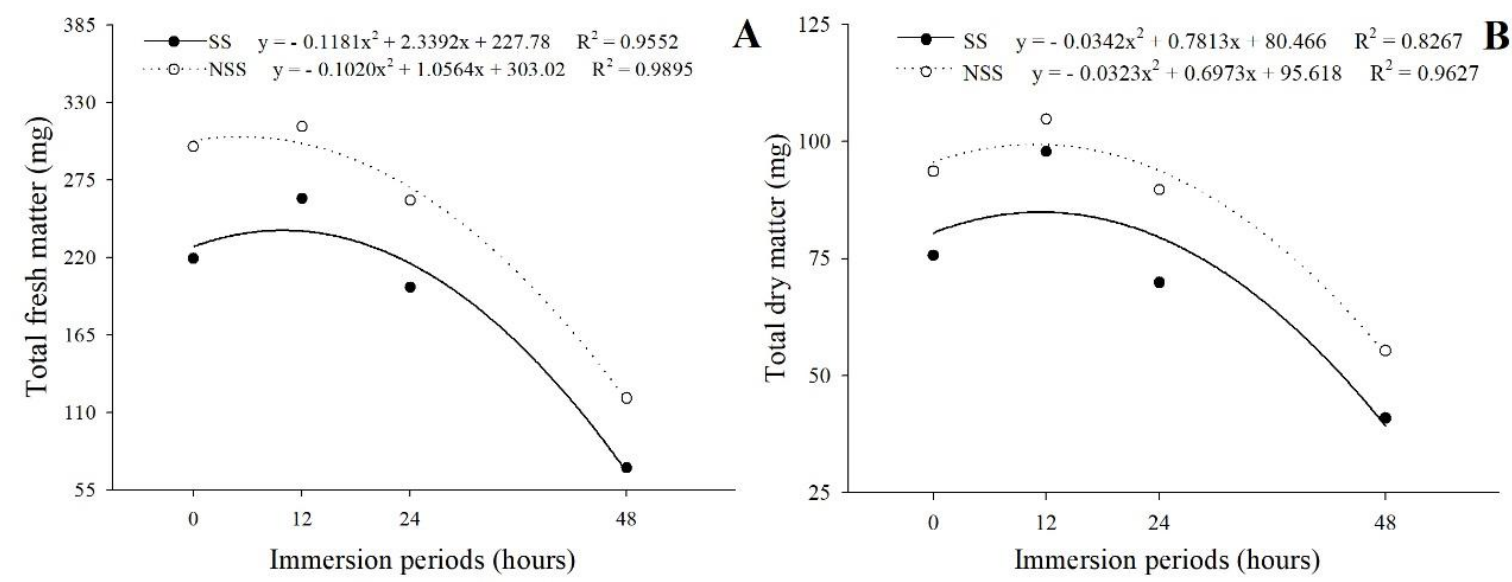

Fig 2. Total fresh (A) and dry (B) matter of pomegranate seedlings (Punica granatum L.) according to the presence (SS) or absence (NSS) of seeds scarification during water immersion periods.

Table 3. Analysis of variance for leaf number (LN), stem diameter (SD), root system length (RSL) and shoot length (SL) in pomegranate seeds (Punica granatum L.) under water immersion.

\begin{tabular}{|c|c|c|c|c|}
\hline \multirow{2}{*}{ Variation sources } & $\mathrm{LN}$ & $\mathrm{SD}(\mathrm{mm})$ & $\operatorname{RSL}(\mathrm{cm})$ & $\mathrm{SL}(\mathrm{cm})$ \\
\hline & \multicolumn{4}{|l|}{$p$ Value } \\
\hline Seeds (S) & $0.9803^{\mathrm{ns}}$ & $<0.01^{*}$ & $<0.01^{*}$ & $0.0772^{\mathrm{ns}}$ \\
\hline Immersion (I) & $0.0318^{*}$ & $<0.01^{*}$ & $<0.01^{*}$ & $<0.01^{*}$ \\
\hline $\mathrm{S} \times \mathrm{I}$ & $0.2945^{\mathrm{ns}}$ & $<0.01^{*}$ & $0.3357^{\text {ns }}$ & $<0.01^{*}$ \\
\hline C.V. (\%) & 23.83 & 25.45 & 24.04 & 15.53 \\
\hline Overall mean & 3.01 & 0.44 & 7.41 & 3.66 \\
\hline Seeds & \multicolumn{4}{|c|}{ Overall mean } \\
\hline Non-scarified & 9.69 & 0.46 & 7.84 & 3.73 \\
\hline Scarified & 9.66 & 0.41 & 6.92 & 3.57 \\
\hline Immersion (hours) & \multicolumn{4}{|c|}{ Overall mean } \\
\hline 0 & 9.83 & 0.58 & 8.34 & 3.91 \\
\hline 12 & 10.63 & 0.50 & 7.55 & 4.13 \\
\hline 24 & 11.23 & 0.35 & 6.83 & 4.01 \\
\hline 48 & 6.13 & 0.28 & 6.77 & 2.21 \\
\hline
\end{tabular}

"Significant; ${ }^{\text {NS }}$ Not significant at $5 \%$ probability by F test; C.V. = Coefficient of variation.

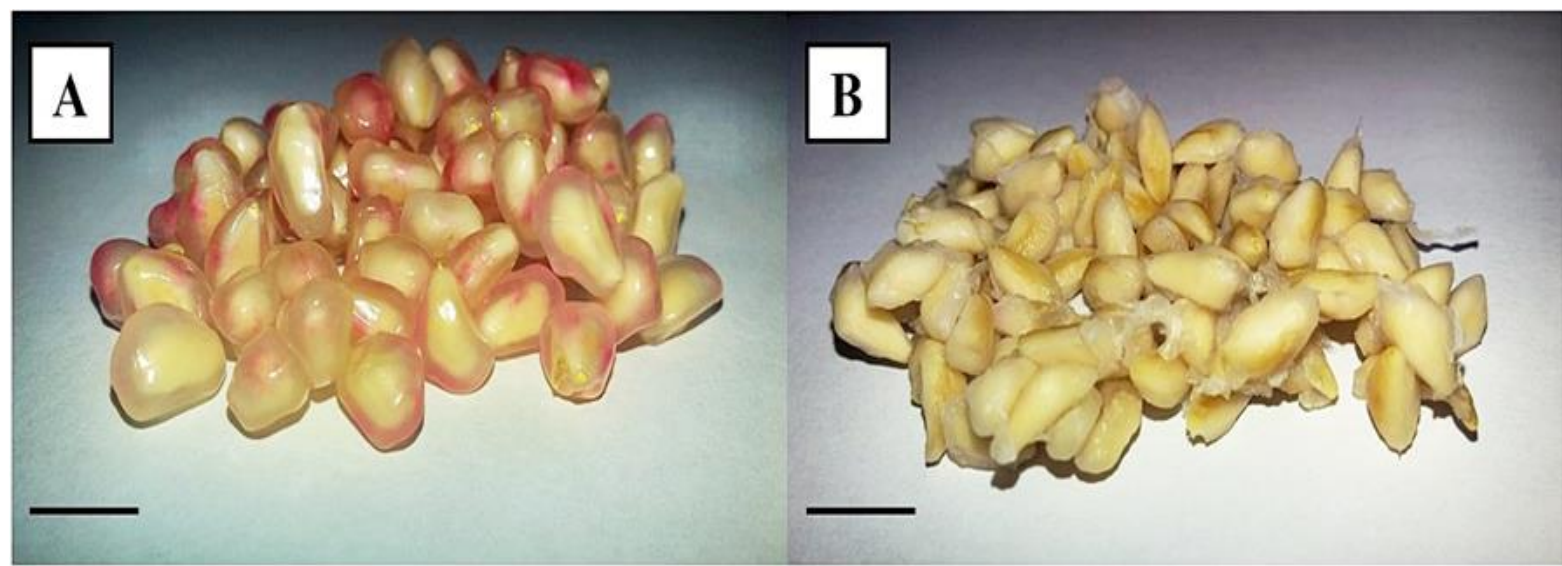

Fig 3. Pomegranate seeds (Punica granatum L.): with sarcotesta (A) and without sarcotesta (B). Bar: $1 \mathrm{~cm}$. 
Table 4. Analysis of variance for total fresh matter (TFM) and total dry matter (TDM) in pomegranate seeds (Punica granatum L.) immersed in water.

\begin{tabular}{|c|c|c|}
\hline \multirow{2}{*}{ Treatments } & TFM (mg) & TDM (mg) \\
\hline & \multicolumn{2}{|c|}{$\mathrm{p}$ Value } \\
\hline Seeds (S) & $<0.01^{*}$ & $<0.01^{*}$ \\
\hline Immersion (I) & $<0.01^{*}$ & $<0.01^{*}$ \\
\hline $5 \times 1$ & $<0.01^{*}$ & $0.0445^{*}$ \\
\hline C.V. (\%) & 23.97 & 21.00 \\
\hline Overall mean & 0.23 & 0.08 \\
\hline Seeds & \multicolumn{2}{|c|}{ Overall mean } \\
\hline Non-scarified & 0.20 & 0.09 \\
\hline Scarified & 0.25 & 0.08 \\
\hline Immersion (h) & \multicolumn{2}{|c|}{ Overall mean } \\
\hline 0 & 0.26 & 0.08 \\
\hline 12 & 0.29 & 0.10 \\
\hline 24 & 0.23 & 0.08 \\
\hline 48 & 0.10 & 0.05 \\
\hline
\end{tabular}

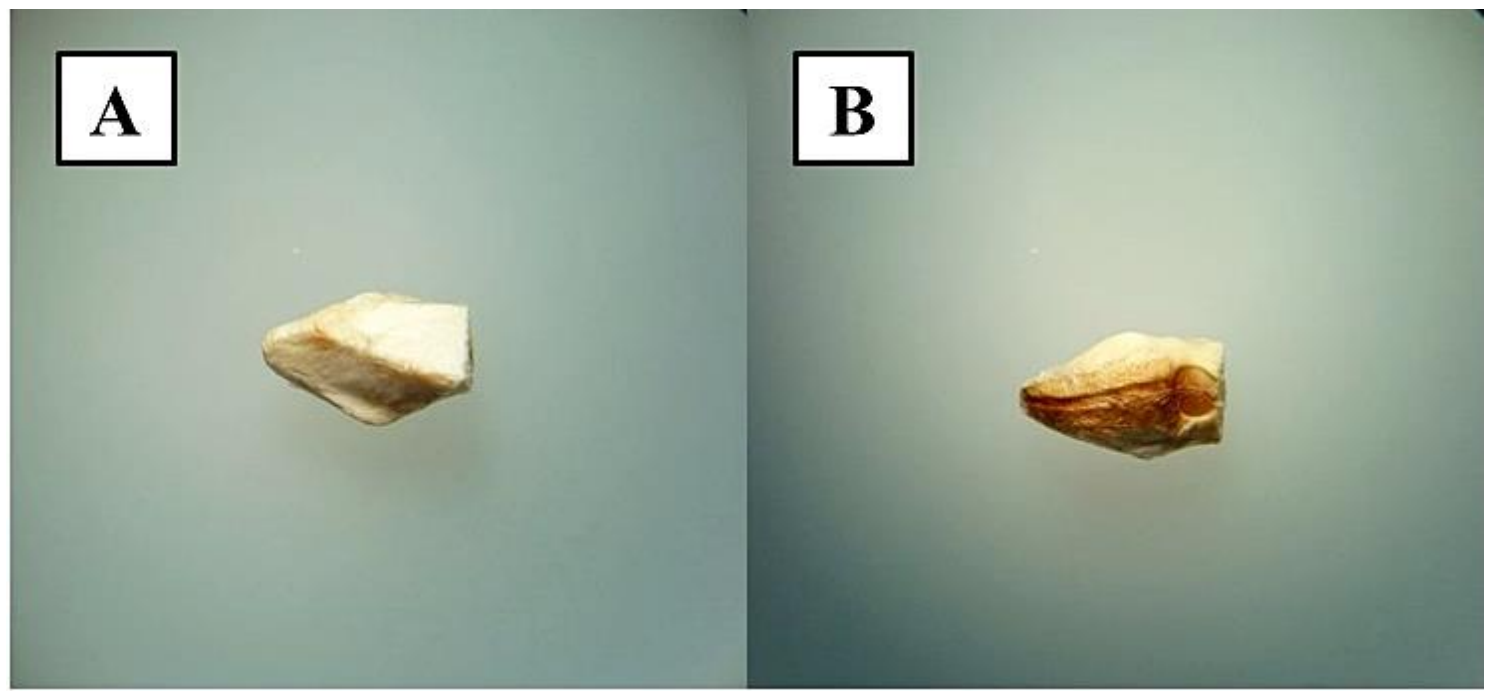

Fig 4. Scarified pomegranate seeds (Punica granatum L.): ventral (A) and dorsal (B) view. Increase scale by $0.7 x$.

Some authors reported a decrease in mean time of emergence (MTE) of papaya (Carica papaya L.) that can be achieved by removing the sarcotesta from seeds, (Gherardi and Valio, 1976; Perez et al., 1980), as performed in pomegranate seeds of the current study.

For scarified seeds, the lowest MTE (15.96 days $\left.{ }^{-1}\right)$ value was observed in water immersion for 12 hours, but did not differ significantly from water immersion for 0 and 24 hours (Table 2). Moreover, non-scarified seeds did not show significant difference for MTE, but the lowest value was verified without water immersion. Furthermore, it is preferable to have low MTE values, as they reduce seedlings production time, besides guaranteeing uniformity among them, due to the smaller difference between sowing and emergence period.

\section{Initial growth evaluation of pomegranate seedlings}

Table 3 demonstrates mean squared and mean values of the initial seedling growth variables. Leaf number (LN) and root system length (RSL) had no interaction between seed and water immersion, with an overall mean of 3.01 (LN) and $7.41 \mathrm{~cm}$ (RSL).

Although scarified seeds have raised pomegranate seedlings with high $L N$ than non-scarified in water immersion for 0 hours, there was a significant decrease in first seed group, when imbibition period increased. Leaf number is an important trait to be considered, as they support potential crop yield, since leaves are one of the main organs that integrate respiratory process, which exchange gases with environment (Pereira et al., 1997).

For leaf number, there was more variation on scarified seed values (8.60) than non-scarified ones (4.00). The highest values were found in seeds with and without scarification (i.e. 12.80 and 11.10 , respectively) in water immersion for 0 hours, with no significant difference between them. These results indicate that water immersion periods directly and negatively influenced LN.

For root system length (RSL), there was a reduction according to water immersion periods. In seedlings with or without scarification, values were higher in water immersion for 0 hours than other treatments. 
No-scarified seeds raised seedlings with higher RSL than scarified ones, unlike those found in cheese fruit (Morinda citrifolia L.) and 'quixabeira' (Sideroxylon obtusifolium) seeds by Oliveira et al. (2011) and Rebouças et al. (2012), respectively.

When both seed groups were not immersed in water, the highest values of LN and RSL were obtained; therefore, the source and drain relationship between roots and aerial portions of the plant was achieved (Pereira et al., 2008). The high $\mathrm{LN}$ value probably enabled RSL, since photo assimilates produced in photosynthesis are used in seedling development and growth, intensifying the connections between leaf and roots, as they absorb nutrients from environment (Suassuna et al., 2010).

Thus, scarified seeds yielded seedlings with lower RSL than seedlings from non-scarified seeds in all water immersion periods. Through scarification, the water inflow was facilitated in seeds, which rapidly absorbed moisture; therefore, it probably damaged due to reduction in the integrity of cell membranes, besides losing essential nutrients (Cavalcante et al., 2008; Costa et al., 2008).

Figure $1 \mathrm{~A}$ shows that the highest stem diameter (SD) values in scarified $(0.53 \mathrm{~mm})$ and non-scarified $(0.62 \mathrm{~mm})$ seeds were obtained in water immersion for 0 hours. Those are responses of activities made by the largest amounts of leaves found in the same water immersion period. For SD growth, some exchanged activities must be occurring from apical areas by photosynthetic actions and hormones translocation (Larcher, 2006).

By increasing water immersion periods, the values of SD significantly decreased in both groups of seeds. Also, these results were always lower in scarified seeds than nonscarified ones, independently of immersion period (Figure 1A).

Figure $3 B$ shows that shoot length $(S L)$ of pomegranate seedlings derived from both seed groups presented a quadratic behaviour. According to Oliveira et al. (2011), SL showed higher values in seedlings from non-scarified seeds of cheese fruit, especially when they were not immersed in water (Figure 1B). Therefore, pomegranate seeds have a considerable amount of water in their composition and, even with intact integument, allowing solutes to enter the substrate to their interior, guaranteeing seedlings emergence without needing imbibition period. Moreover, such observations may indicate that pomegranate seeds are permeable to water, that is, no integumentary dormancy.

Table 4 demonstrates that interaction between seeds and water immersion periods was significant for both total fresh matter (TFM) and total dry matter (TDM).

Regarding to both TFM and TDM, non-scarified seeds were superior to scarified ones in all water immersion periods (Figure 2A and 2B), unlike those found in 'biriba' scarified seeds (Rollinia mucosa), which presented high dry matter values in water immersion for 24 hours (Ferreira et al., 2009).

With regards to TFM, scarified and non-scarified seeds behaved similar to all over immersion periods, being the highest values found at 12 hours (261.82 and $312.94 \mathrm{mg}$, respectively) and the lowest values at 48 hours (70.76 and $120.11 \mathrm{mg}$, respectively) (Figure 2A).

For TDM (Figure 2B), the highest value was observed in seedlings raised from non-scarified seeds immersed in water for 24 hours. These results are unlike the one found in cheese fruit seeds, as the highest value was observed in scarified seeds in water immersion for 48 hours (Oliveira et al., 2011).

When scarified seeds of pomegranate remained for up to 48 hours under water immersion in the current study, TDM $(40.88 \mathrm{mg}$ ) probably declined due to the excess of water, since seed may have rapidly absorbed water under these conditions; consequently, tissues were probably ruptured (Carvalho and Nakagawa, 2012).

When pomegranate seeds were scarified without water immersion, seedlings did not present high TDM values (Figure 2B), because integument was probably ruptured, leaching out essential substances for embryo; consequently, seedling development hindered biomass production (Zuchi et al., 2012).

Therefore, non-scarified seeds in water immersion behaved in a prominent or similar way to the values reported by scarified seeds. Therefore, integument rupture was unnecessary in pomegranate seeds.

\section{Materials and Methods}

The current experiment was performed at the Laboratory on Department of Plant Technology, Food Technology and Socioeconomics (UNESP), Ilha Solteira.

\section{Plant material}

Mature fruits of pomegranate cultivar Comum were harvested from adult plants in a commercial orchard located in Presidente Prudente $\left(22^{\circ} 3^{\prime} 21.24\right.$ "S 51 $21^{\circ} 35.16 " \mathrm{~W}$ and an altitude of $477.6 \mathrm{~m}$ ). According to Köppen climate classification, the region is classified as $A w$, that is, rainy tropical wet-dry climate (Rolim et al., 2007).

\section{Pre-sowing treatments on seed germination and experiment installation}

Seeds were removed from fruits and homogenized (Figure $3 \mathrm{~A})$. Then sarcotesta were efficiently removed from seeds by pressuring through a 2-mm sieve in running water (Figure 3B) (Melo and Seleguini, 2013).

After removal of the sarcotesta, the material was separated into two lots: intact seeds and scarification that involved partial removal of the seed coat on the side of the hilum, opposite the radicle, with the aid of 100 grit sandpaper (Figure 4). Both lots were totally immersed in deionised water and gently stirred with a magnetic stirrer for periods of $0,12,24$ and $48 \mathrm{~h}$ at $25^{\circ} \mathrm{C}$. The solution was exchanged every 2 hours. After the pre-sowing treatments, seeds were sown in polystyrene trays, which had 200 cells filled with commercial substrate (Bioplant ${ }^{\circ}$ ) at a greenhouse equipped with fan and pad evaporative cooling system (28 \pm $\left.2^{\circ} \mathrm{C}\right)$. Irrigation was performed twice a day for 3 minutes at a flow rate of $1800 \mathrm{~cm}^{3} \mathrm{~min}^{-1}$.

\section{Seedling emergence and biometric assessments}

The following evaluations were made until seedling emergence and establishment: initial emergence (days); final emergence (\%) (Brasil, 2009); speed index (Maguire, 1962) and mean time of emergence (days ${ }^{-1}$ ) (Labouriau, 1983). 
At 50 days after sowing, the leaf number, stem diameter $(\mathrm{mm})$, length of aerial part $(\mathrm{cm})$ and root system $(\mathrm{cm})$, fresh matter $(\mathrm{mg})$ and total dry matter $(\mathrm{mg})$ were evaluated.

To determine total dry matter, seedlings were placed in paper bags and dried in forced air flow oven at $60^{\circ} \mathrm{C}$ until reaching constant mass ( 72 hours), then weighed in a precision analytical balance $(0.0001 \mathrm{~g})$.

\section{Experimental design and statistical analyses}

A $2 \times 4$ factorial arrangement (presence or absence of scarification $x$ immersion time) in a completely randomized design was used, with 4 replicates of 25 seeds each. Data were submitted to analysis of variance by F-test and means were compared by Scott-Knott test, both at $5 \%$ probability ( $p<0.05$ ), and adjusted to the polynomial regression, using SISVAR software 5.6 (Ferreira, 2014).

\section{Conclusion}

Mechanical scarification and water immersion was unnecessary on pomegranate seeds to speed up seedling emergence. Pre-sowing treatments on seeds did not improve the initial growth of pomegranate seedlings. Pomegranate seeds, cv. Comum, do not present integument related dormancy.

\section{Acknowledgments}

The authors would like to thank the Coordination for the Improvement of Higher Education Personnel (CAPES) for the financial support.

\section{References}

Aguiar RS, Yamamoto LY, Preti EA, Souza GRB, Sbrussi CAG, Oliveira EAP, Assis AM, Roberto SR, Neves CSVJ (2014) Mucilage extraction and substrates in the seedling development of yellow passion fruit plants. Semina: Ciênc Agrár. 35(2): 605-612.

Bewley JD, Bradford KJ, Hilhorst HWM, Nonogaki H (2013) Seeds: physiol-ogy of development, germination and dormancy. 3nd edn. SpringerVerlag, New York.

Brasil (2009) Ministério da Agricultura, Pecuária e Abastecimento. Regras para análise de sementes. 1nd ed. MAPA/ACS, Brasília.

Carvalho NM, Nakagawa J (2012) Sementes: ciência, tecnologia e produção. 5nd ed. FUNEP, Jaboticabal.

Cavalcante JA, Pereira NAE, Nobre RG, Lopes KP, Marques KM (2014) Physiological seed quality of papaya submitted to different methods of removal sarcotesta. Rev Verde. 9(2): 285-290.

Costa CJ, Villela FA, Bertoncello MR, Tillmann MÂA, Menezes NL (2008) Isoenzymatic expression after pea seed prehydration. Rev Bras Sementes. 30(3): 130-138.

Dutra TR, Massad MD, Sarmento MFQ, Costa JO (2012) Emergence and early growth of canafístula on different substrates and methods of dormancy breaking. Rev Caatinga. 25(2): 65-71

Elfalleh W, Tlili N, Nasri N, Yahia Y, Hannachi H, Chaira N, Ying M, Ferchichi A (2011) Antioxidant capacities of phenolic compounds and tocopherols from Tuni-sian pomegranate (Punica granatum) fruits. J Food Sci. 76(5): 707-713.

El-Sherbini GT, Shoukry NM (2012) In vitro effect of pomegranate peel extract on Trichomonas tenax. Life Sci J. 9(3): 791-797.

Fachinello JC, Hoffmann A, Nachtigal JC (2005) Propagação de plantas frutíferas. Brasília: Embrapa Informação Tecnológica. 221p.

Ferreira DF (2014) Sisvar: a guide for its bootstrap procedures in multiple comparisons. Ciênc agrotec. 38(2): 109-112.

Ferreira EGBS, Matos VP, Gonçalves EP, Ferreira RLC, Silva RB (2014) Pre-germination treatments on the seeds of two species of the genus Poincianella. Rev Ciênc Agron. 45(3): 566-572.

Ferreira MGR, Santos MRA, Silva EO, Gonçalves EP, Alves EU, Bruno RLA (2009) Overcoming dormancy in seeds of Rollinia mucosa (Jacq.) Baill. Rev Bras Sementes. 31(4): 9599.

Ferreira SAN, Gentil DFO (2006) Extraction, imbibition and germination of Astrocaryum aculeatum seeds. Acta Amaz, 36(2): 141-146.

Fischer DLO, Rossarolla MD, Fischer C, Oliveira EL, Giacobbo $\mathrm{CL}$ (2013) Emergence of seedlings of rootstock of the peach when submitted to different periods of stratification. Rev Ciênc Agron. 44(1): 199-204.

Franzon RC, Carpenedo S, Silva JCS (2010) Produção de mudas: principais técnicas utilizadas na propagação de fruteiras. Planaltina: Embrapa Cerrados Documentos 283, $56 p$.

Gherardi E, Valio JM (1976) Occurrence of promoting an inhibitory substance in the seed of Carica papaya. J Hortic Sci. 51(1): 1-14.

Ibrahim H, Oladiran JA, Habila J (2011) The effects of sarcotesta and storage temperature on the longevity of seeds of five papaya (Carica papaya) landraces. Int J Sci Nat. 2(4): 727-732.

Labouriau LG (1983) A germinação das sementes. Secretaria Geral da Organização dos Estados Americanos, Washington.

Larcher W (2006) Ecofisiologia vegetal. 3nd ed. RIMA Artes e Textos, São Carlos.

Leite GA, Cunha PSCF, Mendonça LFM, Medeiros PVQ, Mendonça V (2012) Dormancy break in seed of noni. Rev Verde. 7(4): 120-128.

Maguire JD (1962) Speed of germination-aid in selection evolution for seedling emergence and vigor. Crop Sci. 2: 176-177.

Materechera AS, Seeiso TM (2013) Seed treatment to improve water imbibition and germination of pomegranate (Punica granatum). Acta Hort. 979: 713-721.

Melo APC, Seleguini A (2013) Stages of maturity and removal of physical sarcotesta on seedling emergence and development of papaya. Com Sci. 4(1): 20-25.

Mendonça V, Mendonça LFM (2013) Fruticultura tropical: bananeira, cajueiro e mangueira. Mossoró: EdUFERSA. 356p.

Nazário P, Ferreira SAN (2010) Emergence of Astrocaryum aculeatum seedlings according temperature and soaking period of seeds. Acta Amaz. 40(1): 165-170. 
Noda Y, Kaneyuki T, Mori A, Packer L (2002) Antioxidant activities of pome-granate fruit extract and its anthocyanidins: delphinidin, cyaniding and pelargonidin. J Agric Food Chem. 50(1): 166-171.

Oliveira KP, Batista DS, Souza DCF, Benedito CP, Ribeiro MCC (2011) Lopping and soaking in seeds of noni (Morinda citrifolia L.). Rev Bras PI Med. 13: 513-517.

Oliveira OS (2007) Tecnologia de sementes florestais. 1nd ed. Imprensa Universitária, Curitiba.

Peche PM, Barbosa CMA, Pio R, Sousa PHA, Valle MH (2016) Seed stratification, gibberellic acid and temperature in obtaining rootstock in the persimmon. Rev Ciênc Agron. 47(2): 387-392.

Pereira CJ, Schumacher MV, Hoppe JM, Caldeira MVW, Santos EM (1997) Produção de biomassa em um povoamento de Acacia mearnsii de Wild. no Estado do Rio Grande do Sul. Rev Árvore. 21(4): 521-526.

Pereira TB, Alves JD, Abrahão AS, Abrahão JE, Fries DD, Livramento DE, Deuner S (2008) Carbohydrates, nitrate reductase and restoration of "overaged" coffee seedlings after pruning at different heights. Rev Ceres. 55(3): 236242.

Perez A, Reyes MN, Cuevas J (1980) Germination of two papaya varieties: effect of seed aeration, K-treatment, removing of the sarcotesta, high temperature, soaking in dis-tilled water and age of seeds. J Agrie Univ P R. 64(2): 73-180.

Rebouças ACMN, Matos VP, Ferreira RLC, Sena LHM, Sales AGFA, Ferreira EGBS (2012) Methods for overcoming dormancy of quixabeira seeds (Sideroxylon btusifolium (Roem. \& Schult.) T.D.Penn.). Ci Fl. 22(1): 183-192.

Rolim GS, Camargo MBP, Lania DG, Moraes JFL (2007) Climatic classification of köppen and thornthwaite sistems and their applicability in the determination of agroclimatic zonning for the state of São Paulo, Brazil. Bragantia. 66(4): 711-720.

Russo M, Fanali C, Tripodo G, Dugo P, Muleo R, Dugo L, Gara L, Mondello L (2018) Analysis of phenolic compounds in different parts of pomegranate (Punica granatum) fruit by
HPLC-PDA-ESI/MS and evaluation of their antioxidant activity: application to different italian varieties. Anal Bioanal Chem. 410(15): 3507-3520.

Scalon SPQ, Jeromine TS (2013) Substrate and water levels on the germinative potential of seeds of uvaia. Rev Árvore. 37(1): 49-58.

Shalimu D, Li K, Baskin CC, Baskin JM, Liu Y (2015) Seed germination biology of four pomegranate (Punica granatum) cultivars from Xinjiang, China. Hortsci. 50(6): 826-829.

Silva LMM, Mata MERM, Duarte MEM (2015) Water content limit for cryopreservation of pomegranate seeds (Punica granatum L.). Eng Agríc. 35(2): 313-321.

Suassuna JF, Melo AS, Sousa MSS, Costa FS, Fernandes PD, Pereira VM, Brito MEB (2010) Growth and photochemical efficiency in seedlings of passion fruit hybrid under irrigation levels. Biosci J. 26(4): 566-571.

Takata W, Silva EG, Corsato JM, Ferreira G (2014) Germination of pomegranate (Punica granatum L.) seeds under giberellin concentrations. Rev Bras Frutic. 36(1): 254-260.

Vazifeshenas M, Khayyat M, Jamalian S, Samadzadeh A (2009) Effect of different scion-rootstocks combinations on vigor, tree size, yield and fruit quality on three iranian cultivars of pomegranate. Fruits. 64(6): 343-349.

Zaidan LBP, Barbedo CL (2004) Quebra de dormência em sementes. pp. 135-146. In: Ferreira AG, Borguetti $F(e d)$ Germinação: do básico ao aplicado. ARTMED, Porto Alegre.

Zuchi J, Panozzo LE, Heberle E, Araujo EF (2012) Imbibition and electrical conductivity of castor bean seeds classified by size. Rev Bras Sementes. 34(3): 504-509.

Wagner Júnior A, Alexandre RS, Negreiros JRS, Parizzotto A, Bruckner $\mathrm{CH}$ (2005) Influence of seed scarification and imbibition time on passion fruit (Passiflora edulis $\mathrm{f}$. flavicarpa Degener) seed germination. Rev Ceres. 52(301): 369-378. 